FSI Occasional Papers

No. 1 - November 2000-10-25

\title{
The Organisational Structure of Banking Supervision
}

by

Prof. C.A.E. Goodhart

Financial Stability Institute Bank for International Settlements

Basel, Switzerland 
Charles Goodhart, CBE, FBA is the Norman Sosnow Professor of Banking and Finance at the London School of Economics (LSE). Before joining the LSE in 1985, he worked at the Bank of England for seventeen years as a monetary adviser, becoming a Chief Adviser in 1980. In 1997 he was appointed one of the outside independent members of the Bank of England's new Monetary Policy Committee until May 2000. Earlier he had taught at Cambridge and LSE. Besides numerous articles, he has written a couple of books on monetary history, and a graduate monetary textbook, Money, Information and Uncertainty (2nd Ed. 1989); and has published two collections of papers on monetary policy, Monetary Theory and Practice (1984) and The Central Bank and The Financial System (1995); and an institutional study of The Evolution of Central Banks, revised and republished (MIT Press) in 1988. 


\section{Contents}

The Organisational Structure of Banking Supervision

Foreword V

Abstract

vii

I. Introduction

1

II. Arguments for Separation

8

III. Arguments for Unification

24

IV. Are the Issues the Same in Emerging Countries?

34

V. Conclusions

43

Bibliography

45 



\section{Foreword}

It gives me great pleasure to present this first in a series of occasional papers published by the Financial Stability Institute. The purpose of these papers is to create awareness of, and provide information on, topics of interest to financial supervisors. For this first paper the Financial Stability Institute requested Professor Charles Goodhart (London School of Economics) to write about banking supervision and its relationship to central banks.

Traditionally, it has been considered ideal to place banking supervision under the umbrella of central banks because this function is key to the conduct of monetary policy and financial stability oversight.

Recently, many countries around the world have been moving banking supervision outside their central banks. What are the advantages and disadvantages of this policy decision? Professor Charles Goodhart addresses this question. Furthermore, an important contribution of his work is to focus this issue from the point of view of emerging-market countries.

We present this work with the hope that it will provide policy makers with key factors they should take into consideration in the design of the most appropriate structure of their supervisory systems.

John G. Heimann

Chairman

Financial Stability Institute

November 2000 



\section{The Organisational Structure of Banking Supervision}

by Prof. C.A.E. Goodhart ${ }^{1}$

Financial Markets Group

London School of Economics

\section{Abstract}

In this paper I try to address the question of whether, and why, it matters whether banking supervision is undertaken in-house in the Central Bank or in a separate specialised supervisory institution. After all, the banking supervisors and those in the Central Bank concerned with systemic stability must continue to work closely together wherever the supervisors are physically located.

Nevertheless there has been some recent trend towards hiving off banking supervision to a separate agency, as with the Financial Services Authority (FSA) in the UK. The main driving forces behind this tendency are the changing, more blurred, structure of the financial system, and continuing concerns with conflicts of interest. As the dividing lines between differing kinds of financial institutions become increasingly fuzzy (e.g. universal banks), continuing banking supervision by the Central Bank threatens both inefficient overlap between supervisory bodies and a potential creep of Central Bank safety net, and other, responsibilities into ever-widening areas. With the accompanying trend towards Central Bank operational independence in monetary policy, continued Central Bank supervisory

1 My thanks are due to P. Armendariz, C. Briault, G. Caprio, T. Dubouchet, P. Jackson, G. Kaufman, R. de Krivoy, D. Llewellyn, G. Schinasi, D. Schoenmaker, M. Taylor, P. Tucker, D. Walker, W. White, and participants at a BIS seminar for helpful comments. Responsibility for all views and remaining errors remains with me. 
authority enhances concerns about potential conflicts of interest, and raises issues about the limits of delegated powers to a nonelected body.

On the other hand, separation of supervision from the Central Bank raises questions whether systemic stability might suffer. The ethos, culture and concerns of the separate supervisory body might come to focus more on conduct of business and customer protection issues. Potentially systemic financial crises would have to be handled by a committee, not by a unified Central Bank. How much, if at all, would the collection, transmission and interpretation of information relevant to a Central Bank's concerns, both on monetary and systemic stability policy issues, be lost as a consequence of separation?

These are, mostly, qualitative issues, and more developed countries, with differing historical, legal and institutional backgrounds, will, and have, come to differing conclusions. But in less developed countries, more weight needs to be placed on ensuring the quality of the supervisory staff, i.e. their professional skills, independence from external pressures, and adequate funding. These latter considerations tell strongly towards retaining banking supervision under the wing of the Central Bank in emerging countries. 


\section{Introduction}

In 1997 the newly elected Labour Government in the United Kingdom transferred responsibility for the prudential supervision of commercial banks from the Bank of England to a newly established body, the Financial Services Authority (FSA). The FSA was to take on responsibility for, and combine, both the prudential and the conduct of business supervision for virtually all financial institutions (banks of all kinds, finance houses, mutual savings institutions, insurance companies, etc.), and financial markets. So, during the course of 1998 most of the banking supervisors who had been working together in a designated section of the Bank moved together, en bloc, to the new headquarters of the FSA at Canary Wharf, a few miles further east.

The same people continued to do the same job. What then had changed? ${ }^{2}$ Moreover, the commercial confidentiality of their work had meant that their offices in the Bank had previously been sealed off internally from the rest of the Bank (Chinese Walls!). Given the increasing ease of long-distance communication (by e-mail as well as telephone and fax), would channels of information really be that much changed by the physical move?

$\overline{2}$ The FSA would, I believe, argue that what has changed is that it can take advantage of the efficiency benefits of a unified supervisor, to be discussed in Section (II)(a) below, by putting greater emphasis on the integrated supervision of financial groups, and, more generally, put the regulation of banks on a basis that is more closely correlated with the regulation of other parts of the financial services industry (see 'A New Regulator for the New Millennium', FSA (2000)). 
One possible answer could be that both the physical location and the organisational structure of the financial supervision of banks are, indeed, a second-order problem. It is not the purpose, or intention, of this paper to argue whether, and if so exactly how, financial institutions need to be supervised. On the maintained assumption that some such supervision will continue to be needed, the banking/financial supervisors will have to work closely with the Central Bank, and vice versa, whatever the organisational structure.

However much the Central Bank is focussed on macro-economic issues of monetary and price stability, the achievement of such macro objectives rests on the basis of maintaining micro-level financial stability, in the payments system, in the banking system, and the smooth working of the financial system more broadly. So the Central Bank will have an on-going concern for financial stability and financial regulation; a Central Bank will feel that it needs to be in close and continuous contact with the supervisory body, however that may be organised. By the same token, the health and profitability of the financial system depend on the macro-conjuncture; the supervisory authorities will want to learn from the Central Bank what may be expected on this front.

No one particularly likes having an older relative looking over their shoulder, and an independent supervisory body may be jealous of its own independence. Indeed, such amour propre may be one of the obstacles to a full and satisfactory flow of information. Nevertheless a sensible supervisory authority would realise both that the Central Bank should act as a partner in any proposed change in the regulatory structure, and that, as a supervisory body, it has no ability on its own to provide financing (to lend or to create money) to financial institutions needing some financial injection. Again, it is not the purpose of this paper to argue whether, when and how Lender of Last Resort (LOLR) functions should be carried out. But, should the supervisory 
body want to propose the injection of extra funding into the financial system, it needs to obtain the approval of the Central Bank (and nowadays in most cases also of the Ministry of Finance) so to do. In the first instance, and normally, LOLR functions would be carried out by the Central Bank. It is certainly possible to conceive of a banking supervisor approaching its own Ministry of Finance directly in order to use taxpayers' funds to obtain resources for such a financial injection. But if that were done behind the back, or against the professional wishes, of that country's Central Bank, it would surely trigger the resignation of that Bank's Governor and a (constitutional) crisis within, and amongst, the monetary authorities. Perhaps the resignation of Miguel Mancera from the Central Bank of Mexico in 1982, when there was an overriding political imperative to bail out banks using public money, could be cited as a possible example.

So, whatever the details and form of organisational structure, those in charge of banking supervision and those in the Central Bank most concerned with financial stability are, perforce, going to have to work together. If so, it could be argued that the precise details of the organisational structure are, at most, of second order importance, and that the scale of attention given to this issue in practice is an indication of the incidence of 'turf wars' rather than of matters of real substance.

In support of this proposition, one can adduce the fact that the organisational relationship between banking supervision and Central Banks has been established in many separate ways in different countries (see Goodhart and Schoenmaker (1995a and b), and Goodhart, Hartmann, et al. (1998)). There are undoubtedly some changing factors that shift the balance towards a preference for one, or other, institutional structure - and these will be discussed further below - as well as changing fashions of viewpoint in this field. Nevertheless the fact that organisational diversity has been so prevalent indicates that it may not have an 
overriding influence on outcomes. Despite some studies claiming to find significant differences on a variety of outcomes dependent on the organisational structure adopted (see, for example, Heller (1991), Briault (1997), and Di Noia and Di Giorgio (1999)), the practical implication of the observed diversity could be that it is not a matter of first moment. Indeed, the problem of trying to assess the best organisational structure is not made easier by the propensity of all institutions, notably including Central Banks, to argue, and with great cogency, that, whatever their present structure may be, it is optimal, or at least would be if some slight additional funding and powers could be made available to it!

If we accept, as a maintained hypothesis, that banking supervisors and the Central Bank should work closely together whatever the organisational structure, why should that structure matter? There are numerous reasons, most of which will be outlined and discussed subsequently. One of the main reasons for concern about such differences is that organisational structure may have some influence on the type of people involved in the exercise of banking supervision, their calibre and professional skills, and the ethos and culture of the organisation in which they work. ${ }^{3}$ At the outset of this Introduction we described how the same individual banking supervisors who had worked at the Bank of England were now still mostly working at the FSA. ${ }^{4}$ But in five, or ten, years time will the skill-structure, outlook and incentives of those working in this capacity at the FSA be the same as if responsibility for this function had remained with the Bank? And will the Bank also retain its skills to handle crises

$\overline{3}$ Schoenmaker and $\mathrm{I}$, with the assistance of some research assistants, are analysing the results of a survey of supervisory bodies on these issues. Unfortunately the results are unlikely to be available until some time in the future.

$\overline{4}$ A study, in a couple of years time perhaps, of who stayed and who left, and why, might be interesting, but is beyond the scope of this paper. 
(see Ferguson (2000) and Greenspan and Federal Reserve Board (1994))? One of the features of this paper is that we shall emphasise the issue of the influence of organisational structure on the personnel involved, particularly with respect to emerging and transitional countries.

In so far as the maintained assumption that banking supervisors and the Central Bank must continue to work closely together, hand in glove, remains, then the obvious (default) solution would seem to be to keep banking supervision within the Central Bank. Information flows must surely be enhanced, differences of view patched up, and decision making expedited and facilitated by such internalisation. The fact that price stability and financial stability go hand-in-hand, and have historically always been seen as doing so, would seem to provide a strong a priori argument in favour of keeping them organisationally unified within the Central Bank $^{5}$ (see Volcker (1984)), though, perhaps, in a semi-detached manner, as has been achieved in recent decades in their various ways in both France and Germany. ${ }^{6}$

5 Pauli (2000) concludes, p. 25, that

'Legal stipulations, appropriateness and strong complementary links form the basis for the central bank's three basic functions: controller of the money supply, settlement agent, and macroprudential supervisor/payment system overseer. Together these constitute an integrated whole. It would not be possible to leave out one of the functions without seriously hampering the conduct to the other two.'

Also see H. Kaufman (2000), p. 219, as follows:-

'As I see it, the proper responsibility of the central bank - assuring the financial well-being of society - requires an intimate involvement in financial supervision and regulation. In fact, I have long believed that it is only the central bank - among the various regulatory agencies that share responsibility in this area-that can represent the perspective of the financial system as a whole. This should be the central organizing principle behind any comprehensive reform of financial regulation and supervision in the United States.'

6 One needs to be careful about interpretation, as David Llewellyn (personal correspondence) has reminded me. What happens in practice is often quite different from what appears to be the case simply by observing the formality of institutional structure. The central bank often has a significant role in supervision even when it is not formally the agency responsible. Practice is seldom as clear-cut as formality. 
Roger Ferguson Jr, a Governor of the Federal Reserve Board, in a 1998 conference speech (published 2000), covered much the same ground as this paper. He was, clearly, making the case for the Federal Reserve maintaining a significant role in banking supervision, a case that the Federal Reserve Board has argued cogently in recent decades (e.g. Volcker (1984) and Greenspan and Federal Reserve Board (1994)). He argued that, p. 301:-

'In the last analysis, there simply is no substitute for understanding the links among supervision, regulation, market behavior, risk taking, prudential standards, and - let us not lose sight - macro stability. The intelligence and know-how that come from our examination and regulatory responsibilities play an important - at times, critical - role in our monetary policy making. No less relevant, our economic stabilization responsibilities contribute to our supervisory policies. Observers and supervisors from single-purpose agencies often lose sight of how too rigorous or too lenient a supervisory stance - or a change in stancecan have serious and significant macro-economic implications, the consideration of which is likely to modify the supervisory policy.

In short, I think the Fed's monetary policy is better because of its supervisory responsibilities, and its supervision and regulation are better because of its stabilization responsibilities.'

And yet the current tide is running now quite strongly in the opposite direction. ${ }^{7}$ The Wallis Report in Australia, the establishment of the FSA in the UK, much of the advice of the IMF to its member countries ${ }^{8}$ (whether developed or not), recent

\footnotetext{
7 See Tuya and Zamalloa (1994).
}

$\overline{8}$ Several Fund officials have, however, written to me personally to say that the Fund is not an unquestioning enthusiast for unification, and prefers a country-by-country (case-bycase) approach. 
developments in Korea and Japan, ${ }^{9}$ and proposals in South Africa and India, all have moved towards the separation of financial supervision from Central Banks. ${ }^{10}$ In the eurozone a separation between monetary policy (at the federal level) and banking supervision (at the national level) has occurred de facto, though many commentators are unhappy with this separation (see Goodhart (2000), and Dubouchet (2000)). Such separation has already been established in most Scandinavian countries (Denmark, Iceland, Norway and Sweden). ${ }^{11}$ Indeed, there are cogent reasons advanced for advocating such a separation, and the grounds for this shift have become stronger in the light of current developments. Partly because we have started, in this Introduction, by setting out the historical, a priori, case for internalising banking supervision within the Central Bank, we shall move on next in Section (II) to outlining the reasons advanced for separation. We shall do so first within the context of more developed countries. Then, in Section (III), we shall return to arguments in favour of combination, again sticking primarily to the case as seen amongst developed countries. In Section (IV) we shall move on to review some of the additional issues relevant particularly to developing and emerging countries. Section (V) concludes, and contains some suggestions for future research.

9 Although Japan has now established a single regulator (very similar to the FSA in the UK), the Bank of Japan still undertakes on-site inspections of major banks, i.e. those which are its counterparties in the payments system.

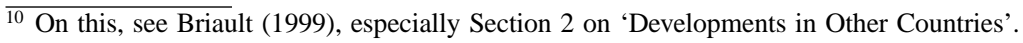
Others, however, would contend that the momentum towards separation is not that strong. One Central Bank regulator has written to me (personal correspondence) as follows:-

'You may have overstated the 'trend' towards separation of banking supervision from central banks, at least in the developed world. When we looked at the Basel Committee members, we found that only one - UK-had taken away banking supervision from its central bank since the Committee was founded. There were a number of other countries where the central bank was not the main banking supervisory agency, but these were very long standing arrangements.'

${ }^{11}$ See How Countries Supervise their Banks, Insurers and Securities Markets, (1999), and Taylor and Fleming (1999). 


\section{Arguments for Separation}

\section{a) The Changing Structure of the Financial System}

Initially in the course of development commercial banks have provided most of the services of financial intermediation. When, thereafter, a variety of other financial intermediary services developed, e.g. investment banking, insurance, fund management, etc., etc., it so happened historically (notably between 1930 and 1970) that macro-economic developments and the fashion of policy led to the enforcement of strict demarcation lines between the various financial intermediaries and their functions, e.g. the Glass-Steagall Act in the USA. Moreover, for much of this period (1930-1970) and in many countries, there were direct controls on competition between such intermediaries, and on the quantities, and pricing, of the business that they could do. The quid pro quo for the existing intermediaries was control over new entry and the establishment of controlled prices/interest rates at levels that ensured a comfortable franchise value. The result, in many cases, was the establishment of cartelised clubs of semi-specialised intermediaries, for whom the oligopolistic structure, and with official encouragement, led to the establishment of largely self-regulating clubs with agreed rules of conduct.

This oligopolistic structure, with limited competition and guaranteed franchise value, reduced the likelihood of financial failure; following the recovery from the great depression in the 1930s until the 1970s, the incidence of financial failure and crises plummeted, partly because of international stability achieved by the Bretton Woods arrangements. This reduced, in- 
deed almost obviated, the need for hands-on banking, and financial, supervision. Until the Fringe Banking Crisis in 1974/75, the Bank of England restricted their direct supervision to a small number of Merchant Banks (the Accepting Houses) and to the Discount Market, stemming from the Bank's own credit exposures. The supervisory function was carried out by one single senior official, the Principal of the Discount Office, with a handful of staff! So, historically, the conduct of banking supervision did not, in practice, play a really large, or central, role in Central Bank activities ${ }^{12}$ because the structure both reduced the need for such an exercise and allowed it to be largely achieved through self-regulation (though this may have been particularly so in the UK, and less representative of other countries). In the USA, the Federal Reserve only really became a major player in banking regulation and supervision with the enactment of the Bank Holding Company Act in 1956, which gave it authority over Bank Holding Companies. ${ }^{13}$

Limitation of competition and oligopoly hindered competition, efficiency and innovation. The protected and regulated financial system that emerged after the end of World War II eventually gave way under the assault of international competition (mostly emanating from the USA); technological innovation (mostly in information technology); a drive for greater efficiency and improved services for customers; and a return to enthusiasm for liberal, market-based, ideology. The greater competition placed downward pressure on profitability, capital ratios and franchise values. Financial instability and failures became more prevalent. Central Banks found themselves increasingly involved in supervisory activities. Some would add that poorly

${ }^{12}$ My colleague, Dirk Schoenmaker, reminds me that banking supervision started seriously rather earlier in some continental European countries, Germany with the Reich Banking Law of 1934, and the Netherlands with its Banking Law of 1948.

$\overline{{ }^{13} \text { I am indebted to G }}$. Kaufman for this information. 
designed regulation and safety nets then became a further cause of bank failures.

These same forces, however, were blurring the previously clear boundaries between categories of financial intermediaries. Universal banking became more popular and commonplace. Banking became mingled with insurance, bank assurance, and both undertook fund management. Eventually that meant that the attempt to supervise separately by function, e.g. commercial banking, investment banking, fund management, etc., would involve a multiplicity of separate supervisors, all crawling over parts of the same single institution. This was hardly efficient or cost effective.

The boundaries between financial intermediaries had become thoroughly blurred. ${ }^{14}$ Borio and Filosa (1994) were, perhaps, the first to explore the consequences of this for the structure of financial supervision (also see Abrams and Taylor (forthcoming)). So one obvious conclusion that was reached was equivalently to place responsibility for the supervision of all financial intermediaries in one institution. But this naturally caused a problem for Central Banks, should they wish to maintain internal control of banking supervision. The logic of placing all supervision under one roof would then require the Central Bank to take responsibility for supervision over activities which lay outside its historical sphere of expertise and responsibility. An even more serious problem, than already exists, would arise of how to demarcate the boundaries between those sub-sets of depositors/institutions which would be covered by the 'safetynet' (explicit or implicit), deposit insurance, Lender of Last Resort facilities, etc., and those not so covered. Would the

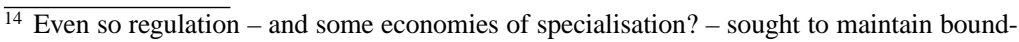
aries between financial and non-financial businesses, with only limited success in some notorious cases, e.g. Russia. 
Central Bank really want to take under its wing the responsibility for customer protection in fund management? In practice, much of staff time, even in banking supervision, is taken up with customer protection issues (other than deposit insurance). Would a Central Bank really want to extend its operational remit to dealing with financial markets and institutions where issues relating to systemic stability were limited, and customer protection of much greater importance, e.g. the pension mis-selling scandal in the UK? So if efficiency and cost saving implied the unification of financial supervision, this suggested placing such a unified body outside the Central Bank (see, for an excellent exposition, Briault (1999)).

But did it necessarily imply such unification? One alternative proposal was to divide the structure of supervision not by market function, e.g. banking, insurance, fund management, but by the purpose of supervision. Here the suggestion was that supervision should be organised around the two purposes of systemic stability (prudential supervision) on the one hand and customer protection (conduct of business supervision) on the other; this was the Twin Peaks proposal, pushed in the UK primarily in the work of Michael Taylor (1995 and 1996). The supervisory body charged with customer protection would naturally take the lead in some areas, markets and institutions. Per contra, the body charged with responsibility for systemic stability would take the lead in dealing with the payments system, and with certain aspects of banking and, perhaps, other financial markets. Even so, there would remain considerable overlaps and duplication.

There are residual vestiges of the Twin Peaks concept in the more unified systems adopted, e.g. in Australia and the UK. The Central Bank usually maintains control of overseeing the payments mechanisms, and will have a much closer involvement in those aspects of supervision potentially raising systemic concerns. Nevertheless the Twin Peaks concept has, so far, not found favour in practice, though, in a slightly inchoate manner, 
the US system has evolved in a way that approximates to it, with the Federal Reserve coming close to a systemic stability (prudential) supervisor, and the SEC undertaking the conduct of business role.

It is not clear, to me at least, quite why this has been so. There would, undoubtedly, have been room for overlap and friction between the two bodies involved; and having to deal with two sets of supervisors would raise the cost to the supervised entities. On the other hand, there would have been some merit in focussing each of the bodies on one particular purpose. A concern that some have is that customer protection is almost certain to take up the greater bulk of the staff's workload within a unified supervisory body. Might then the requirements of maintaining systemic stability, which has in the longer run larger effects on real incomes and national wealth, come to play second fiddle to a culture and ethos concentrating on customer protection? Pauli (2000) comments that, 'The different focus as between investor protection and systemic stability is however so pronounced that there are good arguments for having the primary responsibilities for these two functions divided between separate bodies.' 15

If the Twin Peaks concept had been adopted, it would have been odd if the systemic stability group of supervisors had not been kept within - or under the umbrella of - the Central Bank. One reason for moving to a unified system may, indeed, have been to extract supervisory responsibilities altogether from the Central Bank. We shall come to reasons for advocating this shortly.

\footnotetext{
${ }^{15}$ Ferguson, op cit, similarly argues, p. 299, as follows:-

'But, I would also note that the argument for a single supervisory authority for all financial institutions contains a real risk - the risk of extending supervision and regulation because the agency with the single mission tends to forget or pay less attention to other purposes, such as the effects of its actions on the economy.'
} 
In practice, however, (a) to a large extent a 'systemic stability' regulator and a 'customer protection' regulator would approach the regulation of a large bank in exactly the same way (so there would be considerable duplication and overlap), and (b) as with the FSA and its multiple statutory objectives, there is no reason why a single regulator should not combine a number of objectives and fine-tune its regulatory approach accordingly. ${ }^{16}$

A somewhat different distinction, than between systemic stability and customer protection issues, is that between top-down (macro) and bottom-up (micro) approaches towards these same issues. Most customer protection issues are micro, whereas some prudential, stability issues are macro, with some micro. It can be, and has been, argued that dividing the systemic stability issues between top-down macro, kept with the Central Bank, e.g. in the UK and in Australia, and bottom-up micro, all with an independent agency (or agencies), reinforces clarity and responsibility.

${ }^{16}$ Clive Briault, op cit, writes:-

'[T]he distinction between prudential and conduct of business regulation is not in practice as neat and simple as Taylor's twin peaks model might imply. Even without the emergence of financial conglomerates, a large number of financial services firms would need to be regulated by both of his proposed Commissions because their business would require both prudential and conduct of business regulation. This would certainly include life insurance companies, securities firms and institutional fund managers, and in practice would also include the many banks and building societies who combine deposit-taking with various forms of investment business. This in turn would generate inefficiencies (firms having to be authorised and supervised by more than one regulator) and the possibility of the communication, co-operation and consistency problems discussed earlier.

Moreover, there is a considerable overlap - both conceptually and in practice - between prudential and conduct of business regulation. Both have a close and legitimate interest in the senior management of any financial institution subject to both of these types of regulation, in particular because of the crucial roles of senior management in setting the 'compliance culture' of a firm, in ensuring that management responsibilities are properly allocated and cover comprehensively the business of the firm, and in ensuring that other internal systems and controls are in place. The detail of some of these systems and controls may indeed be specific to either prudential or conduct of business considerations, but many of them will be more general.' 
For example, in its Annual Report, June 2000, the BIS is concerned that a purely micro-level concern with the treatment of risk could have unforeseen, and unintended, effects at the aggregate level. ${ }^{17}$ This might be dealt with best by interacting the top-down expertise of the Central Bank with the bottom-up approach of the supervisor. If both approaches were subsumed within the Central Bank, one or other might be suppressed or overlooked.

\section{b) International Issues?}

First, however, we should also note that amongst the boundaries that have been crumbling have been the geographical limitations of the financial activities of commercial institutions to their own nation state. The largest financial entities are now multinational. The contrast between such multinational commercial activities and the inevitable reliance of regulators and supervisors on national laws (since regulation depends on law, and law-making is in the domain of the sovereign state), produces many strains, see for example the G30 paper on Global Institutions, National Supervision and Systemic Risk (1997). It is, however, far less clear whether, and why, such commercial multinationalism would influence the choice of national structure.

$\overline{17}$ BIS, op cit, p. 149

'[M]uch more attention should be paid by the public sector to monitoring developments and to developing analytical procedures for evaluating the risk of systemic problems. Indeed, using stress tests as a corollary to such forecasts also has a lot to recommend it. Whether analyses of this sort should be done primarily by supervisors or by other bodies (commonly central banks) charged with overall responsibility for systemic stability, or by both, needs to be clarified to ensure that this important function does not simply fall between the cracks. One argument for involving central banks is that there may be a useful complementarity between their 'top down' approach and the 'bottom up' approach more commonly followed by the supervisory community. It is a simple but important insight that many recommendations supporting prudent behaviour at the level of a single firm can have undesirable effects if a large number of firms have simultaneously to alter their behaviour in the same way. Fallacies of composition of this kind are well known in the macroeconomic literature.' 
In so far as (most of) the major banks in any one country have their headquarters, and site of consolidated supervisory oversight, in another country, that would imply that the (smaller) country dominated by foreign banks might take a somewhat more relaxed view of banking supervision (e.g. New Zealand). But such a possible relaxation could occur whatever the domestic structure. Such multinational commercial activity places greater emphasis on cross-country co-operation amongst regulators and supervisors; for example, who provides the financial support and who takes on the fiscal loss in the case of the collapse of an international bank? Central Banks have been renowned for their collegial approach, fostered by the good offices of the BIS. But international co-operation on such issues is hardly going to be damaged if each country should now send two representatives (i.e. from its Central Bank and its separate supervisory body) to the Basel meetings of supervisors. ${ }^{18}$ It is sometimes suggested that the multinational operations of major banks, and other financial entities, may reduce the ability of domestic Central Banks to control macro-economic monetary policy within their own country. But so long as the Central Bank maintains a floating exchange rate regime, its capacity to control its own short-term interest rate, and growth rate for the monetary aggregates, is not impaired by the global spread of business. The Central Bank will maintain as much concern for price stability, and with that for financial stability, in a world of international commercial entities, as it had when its financial firms were overwhelmingly national in coverage.

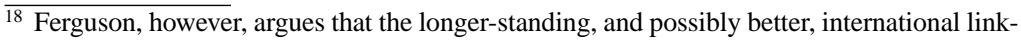
ages of Central Banks provides yet another argument for keeping banking supervision in Central Banks. Thus he writes, p. 300, that

'Globalization of financial markets means that crises in any financial market have significant effects in other nations' markets - in fact, there is increasingly only one global financial market with the interbank connections occurring in both credit and payments flows. The institutions best able to coordinate and address these problems are the world's Central Banks.' 
The assessment of the situation changes, however, when the Central Bank switches from a floating exchange rate to a fixed rate. The extent of fixity can vary from an irrevocably unified exchange rate, as in the eurozone, through dollarisation, as in Panama and now in Ecuador, through to a Currency Board regime, as in Argentina, Estonia and Hong Kong. In each case the Central Bank loses the power to control macro-economic monetary policy. That consideration tells both ways. On the one hand, if Central Banks are to lose their macro-economic role, what is to be their function, their raison d'etre, if they do not hold on to their other responsibilities, notably for supervision? Indeed, a radical might ask whether, without some supervisory function, they will really be needed at all in future; perhaps just an historical (and expensive) monument. Concerns for institutional survival will cause Central Banks when stripped of their macro-economic role to argue more strenuously for retention of their other activities, notably banking supervision.

But by the same token Central Banks in such a subsidiary state (subsidiary to a hegemonic Central Bank, e.g. the European Central Bank (ECB) or Federal Reserve), have less ability to create money (and perhaps undertake LOLR functions, but that issue remains moot for the National Central Banks (NCBs) in the ESCB), on their own. They have less independent power to maintain financial stability. Indeed, the ability of the monetary authorities in some such circumstances to intervene may depend more on the fiscal ability of the Ministry of Finance to make euros/dollars available for financial intervention than on the capacity of the Central Bank to take loans on to its own balance sheet. In such circumstances LOLR becomes even more directly a fiscal measure than a monetary action. So the question of the role of the Central Bank will depend largely on its relationship with the relevant fiscal authorities in the pursuit of financial stability. 
Nevertheless the multinational coverage of the major financial intermediaries means that supervisors and regulators in any one country have a concern with the standards and competence of such supervision/regulation in other countries, especially where such intermediaries may have their headquarters. Such concern can be met (minimally) by the agreement of codes, or principles, of good conduct in these fields. Such codes have proliferated in recent years, multiplying at an almost exponential rate. Beyond codes, there can be agreements on minimum standards, either at a regional level, as in the European Community Directives, or globally, as in the Basel Accords on Capital Adequacy.

It is relatively simple to agree on codes, on what represents good behaviour. It is more difficult to monitor and to apply sanctions for infringement. But international sanctions do exist. Publicity, or 'naming and shaming', is an important instrument, e.g. as used by the Financial Stability Forum to grade the relative status of supervision among off-shore centres. ${ }^{19}$ Beyond publicity, the possibility of excluding intermediaries in the offending countries from financial markets elsewhere would represent a strong, and quite credible, potential punishment.

Perhaps as difficult and important as sanctions is the problem of how to monitor (banking) supervision and regulation elsewhere, an issue of importance in so far as a financial crisis in one country might have contagious spill-over effects on other countries. Suggestions have been made that such international monitoring could be done by one, or other, or a combination of international financial agencies, e.g. BIS, IBRD, IMF, or, perhaps, by a 'col-

\footnotetext{
${ }^{19}$ Such gradings provoked much concern, in some cases fury, amongst the authorities in some centres who felt that they had been judged without due process, without being able to give evidence in rebuttal, and without the possibility of redress. Perhaps, but they could always choose to invite outside observers to attest to their good offices. Moreover the strength of reaction was testimony to the efficacy of the instrument.
} 
lege' of national regulators, i.e. self-regulation for the regulators. But, at the time of writing not much practical advance had been made, and the question 'Quis custodiet ipsos custodes?' remained largely unanswered.

One argument against a unified supervisor that is occasionally heard is that this would prevent any competition between supervisory methods. Greenspan (1994) and the accompanying memorandum from the Board of Governors (1994) argued that a single micro-level regulator, without macro-economic responsibilities, would be more likely to over-regulate and to stifle innovation and risk-taking. But the form of supervisory divisions normally envisaged in most countries would still leave the various supervisors as monopolists in their own areas of responsibility. Moreover, in all smaller, open economies (i.e. virtually everywhere except the USA ${ }^{20}$ and perhaps Japan), the relevant competition with respect to supervisory procedures is international. This is, moreover, measurable, up to a point, by the evidence, and threat, of the regulated to relocate activities to another country/financial centre. On that view any tendency, so far rather notable for its absence, to introduce international harmonisation of legal regulation and supervisory procedures could be seen as a dangerous threat to competition in supervisory practices, not a benefit.

${ }^{20}$ The Shadow Financial Regulatory Committee in the USA issued a Statement on 'The Proposed Federal Banking Commission', No. 100, December 1993, which stated, inter alia, that,

'A potential objection to the Administration's consolidation proposal is that it may harm consumers of financial services in the long run by limiting the regulatory choice that banks have historically had. In the past this choice has often enhanced market competition and facilitated innovation. While this Committee has been receptive to this view in the past, market evolution has lessened the need for regulatory competition in the banking industry. Today, intense competition between banks and nonbank financial institutions provides ample opportunity for consumers of financial services to reap the full benefits of competition and financial innovation.' 


\section{c) The Balance of Power}

As earlier noted, one reason for leaving supervision of the payments and banking system to a subsidiary Central Bank is what else is going to occupy its President and staff? By the same token part of the case for removing supervision from an independent Central Bank is that it, a non-elected body, would otherwise become too powerful. The trend towards giving operational independence to Central Banks has coincided with a trend towards shifting responsibility for (banking) supervision to a separate, specialist and unified, supervisory body. Is this coincidence causal, or accidental?

Democratically elected governments are sovereign. An element of such a sovereign, say the Minister of Finance, is unlikely to want to delegate so much power to another body (the Central Bank) that it might be seen as a separate (and competing?) centre of influence. Nor would it be thought right within a democratic country to cede so much power to a non-elected body. ${ }^{21}$ It may, however, be remarked that such an argument raises some difficult issues in Europe, where the European Commission and its President are also not directly elected.

Whether, and how far, a Parliament may feel that there are limits to the powers that should be delegated to a (independent and unelected) Central Bank, i.e. a pure power play, is uncertain. An alternative, and perhaps better based, reason for the coincidence of enhanced responsibility among Central Banks for operational independence in macro-monetary policy with reduced

$\overline{21}$ But has the move to a single mega-regulator not also concentrated power, though of a somewhat different form, in a non-elected body? Would one argue in the UK, for instance, that the shift from the Bank to the FSA has increased or weakened the concentration of power? One could argue that creating a single regulator has increased the concentration of power though in a different way. I am grateful to David Llewellyn for such thoughts. 
responsibility for supervisory responsibility is that there could be conflicts of interest between the two functions.

\section{d) Conflicts of Interest}

In the introduction, and subsequently, the maintained assumption was that the achievement of monetary and price stability on the one hand, and of financial stability on the other, were natural complements, went hand-in-hand. So the natural implication was that these objectives should be jointly internalised within a single institution, i.e. the Central Bank. The main challenge to that viewpoint comes from those who perceive the ability to conduct good stabilising monetary policy as conflicting with having a simultaneous responsibility for supervision. There are several facets of this argument about conflicts of interest.

The first, and simplest, is that managerial time is limited. Supervisory issues are time-consuming, and in the midst of a financial crisis can distract attention from virtually anything else. Decisions on macro-monetary policy are sufficiently important to want the Governor to concentrate on that, if he/she has operational responsibility for monetary policy. Each job, i.e. monetary decisions and supervisory decisions, is important and separable; a single focus will mean that each will be done better. Complementarities can be handled by consultation and co-operation.

Another aspect of this argument over conflicts is that the conduct of supervision is a thankless task which is all too likely to tarnish the reputation of the supervisor. Academic analysis of monetary operations stresses the importance of being able to influence expectations, and Central Bank practitioners emphasise the importance of credibility. The objectives of macro-monetary policy can, and increasingly are, being set in terms of quantified objectives for inflation targets. This means that the success/ failure of such policy is reasonably transparent. Such quantifica- 
tion and transparency is much more difficult in the case of supervision. Supervision is primarily concerned with the prevention of undesirable events, of systemic instability, of financial failures and of malpractice with respect to rip-offs. The best that a supervisor can expect is that nothing untoward happens. A supervisor is only noticed when either he/she angers the regulated by some restrictive or intrusive action, or when supervision 'fails' in the sense that a financial institution collapses or a customer gets ripped-off. One can talk oneself blue in the face about the desirability of allowing some freedom for banks or other financial institutions to fail, etc., but supervisors will always tend to get bad press when that does happen, come what may. If an independent Central Bank feels the need to achieve credibility and a good reputation, then being yoked with simultaneous responsibility for banking supervision may not be advisable. ${ }^{22}$ Separation may lead to an impression of an Olympian body (i.e. the Central Bank) coming in to pick up the pieces of the failure of more mundane supervisory glitches by the financial supervisory authority.

Beyond the conflicts that may arise from the diversion of scarce managerial attention, and of the danger of association with a body whose failures are obvious (and whose successes have often to remain cloaked in commercial confidentiality), there is the stronger accusation that the internalisation of supervisory concerns may

$\overline{22}$ Some well placed commentators in the UK give considerable weight to this argument. One of them has written to me, as follows:-

'[T]he recent effort to make the Bank's commitment and effectiveness in promoting monetary stability more credible has not been distracted or eroded by retention of a parallel responsibility for financial supervision and customer protection. The fact that there have been no large incidences of failure since the transfer of power is irrelevant: the risk of some failure at some stage remain quite high and one only has to recall the damage done to the Bank's credibility on monetary policy matters in, for example, the late 1980s after the JMB affair, to sense the Bank's vulnerability in a future financial institution or market crisis if it had retained direct supervisory responsibility. I would give rather greater weight to this factor in the paper.' 
lead to worse, wrong, monetary decisions. This is an argument that gets quite a lot of air-time from some economists, ${ }^{23}$ but not one that I find appealing. On this, see Bruni (1997), especially Section 3, pp. 350-4, and the comments of his discussant, Briault. The Shadow Financial Regulatory Committee in the USA is amongst those that believe such conflicts do occur on occasion and may be serious. Thus their Statement no. 153, issued on December 7th, 1998, states that:-

'Indeed, it is the Committee's view that the Fed should not retain responsibility for both monetary policy and the prudential regulation of banks or bank holding companies.

There is at times a clear conflict of interest inherent in the Fed's carrying on roles as both a promoter of stability in the domestic and international financial markets and as a supervisor of banking organizations. This year, as in past years, the Fed has both complained about the relaxation of bank lending standards and encouraged banks to lend to or in foreign countries that were experiencing financial difficulties.'

The claim has been made that this conflict becomes particularly apparent in periods that require more restrictive monetary policy but when large banks are undercapitilized and weak. ${ }^{24}$ It is argued that the Federal Reserve unduly delayed tightening for this reason. I cannot easily assess the validity of that interpretation.

The historical evidence instead suggests that periods of financial instability, and of major, continuing failures among banks are

$\overline{23}$ There is some inverse correlation between Central Banks having supervisory responsibility and their inflation records, see Briault (1997). But this may be due to those Central Banks granted (operational) independence also being stripped of supervisory responsibilities on 'balance of power' grounds.

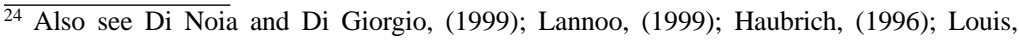
(1995). 
those where monetary policy has been too tight, e.g. Japan since 1991, USA between 1930 and 1939. Declines in the monetary aggregates occur at times of bank failures. Per contra, rapid credit expansion is simultaneously a danger signal for macromonetary policy and for supervisory concern at the micro-level of the individual bank. It would seem to be natural for the micro concerns of supervisors and the macro concerns of the monetary authorities to reflect and complement each other, rather than conflict.

One condition where there could be such conflict is where the prime concern of the monetary authorities is with external objectives, i.e. with exchange rates. It is certainly the case, as was seen in the attempts to hold the ERM in 1992/93 and again in the Asian crisis in 1997/98, that the interest rate deemed necessary to achieve maintenance of the exchange rate could endanger internal financial stability. Perhaps this conflict between internal and external objectives might be influenced somewhat by the direct involvement of the Central Bank with supervisory responsibilities, probably tending to having such a Central Bank give greater weight towards domestic considerations. But would that necessarily be such a bad outcome?

This argument about potential conflicts of interest has been around for a long time, and I have never found it convincing. But when allied with the issue of how to supervise effectively in a world without boundaries either between different kinds of financial activity or between countries, and concerns about the possibly excessive power of an (operationally) independent Central Bank, the arguments for removing (banking) supervision to a separate unified agency, outside the Central Bank, have become stronger and more persuasive in recent years. 


\section{Arguments for Unification}

a) Can Systemic Risk be Resolved by Committee?

Because the (high-powered) reserves of the banking system become centralised in the Central Bank, through the competitive processes of the banking system (see Laidler (1988)), commercial banks which find themselves facing liquidity problems have historically gone to the Central Bank for Lender of Last Resort assistance. ${ }^{25}$ In dealing with such requests, particularly under time pressure, and in conditions when temporary illiquidity is often hard to disentangle from more permanent insolvency, the Central Bank has to weigh the dangers of moral hazard on the one hand from those of systemic instability on the other.

We all have prior judgements about the likely incidence and severity of these two forces, i.e. moral hazard and systemic instability. Those who see moral hazard as an ever-present serious threat, and doubt the prevalence and importance of systemic instability (G. Kaufman (1996); Benston and Kaufman (1995); Schwartz (1995)) would seek to restrict LOLR actions severely, e.g. by setting penal rates. Indeed, there are some who argue that, absent the distortions caused by (explicit or implicit) deposit insurance, the banking system need have no special public sector oversight.

Be that as it may, the Central Bank in virtually all countries has an LOLR function, and is charged with responsibility for so regulating banks that systemic stability is maintained in the pay-

$\overline{25}$ Indeed it was the failure of the National Banking System in the USA to provide such an 'elastic currency' that led to the foundation of the Federal Reserve System in 1913. 
ment and banking systems. How can it possibly discharge these functions adequately unless it has sufficient good information? Would not the transmission of information be most enhanced by locating the banking supervisors within - or under the umbrella of - the Central Bank?

Probably the answer to this latter question is 'yes', but that simply leads on to the next, and much more difficult, issue of how much information flow may be lost when the banking supervisors are separated from the Central Bank? There have been anecdotes, in several countries, that separation does lead to frictions, to barriers, in the free flow of information. But it is extraordinarily difficult to test or to quantify that. Moreover, the behaviour of the newly unified supervisory bodies in their first few years of operation may not prove an accurate indication of their longer-term methods of working.

At a minimum, separation means that information flows are more at risk from the accidents of personality, since it becomes harder for the Governor of the Central Bank to bang the heads of the separate Divisions together. Internal control mechanisms give way to Memoranda of Understanding (MOU), and internal meetings give way to inter-agency committee meetings.

Once upon a time, the handling of a financial crisis was concentrated within the Central Bank. But the Central Bank never had the capital base, or resources, necessary to undertake any large rescues on its own. So, the Central Bank used to turn to the rest of the country's private sector banking system for financial support and other assistance in crisis management. Because of the cartelised, oligopolistic, protected nature of national financial systems, the domestic banks had both the ability and the incentive to comply with such requests. Again, however, such an account may be more representative of the UK (Barings 1890, the Fringe Bank Crisis 1974/75) than of other countries. 
The Central Bank's ability to call on the private banking sector for (financial) assistance has, however, become more difficult, almost impossible, with the advent of the more competitive, multinational system already described in the previous Section. The multinational banks will claim that home country forces, whether shareholders, regulators, or their own domestic law, prevent them from risking their own capital in any coordinated rescue exercise in another country. If the multinationals will not play, then competition will prevent the domestically headquartered banks from doing so either.

That has forced, and will continue to force, Central Banks to turn to their own Ministries of Finance for (taxpayers') funds in order to handle all but the smallest (de minimis) of failures and crises within the banking system. So crisis management, at least in most countries, has already gone beyond the capacity of the Central Bank to handle on its own. The days when the Governor could subsequently inform the Minister of how the Central Bank had sought to resolve the crisis are history. ${ }^{26}$

So crisis management already involves joint co-operation, assessment and agreement between Central Banks and Ministries of Finance. Does it then matter so much if the Committee becomes tri-partite, involving the specialist supervisor, Central Bank and Ministry of Finance? ${ }^{27}$ The prospective Committee

${ }^{26}$ A well-placed commentator observed that:-

'[C]entral banks have become much less capable of exercising the LOLR function independently of the fiscal authorities, i.e. central government. The two principal reasons are that the amounts likely to be required are larger than the capacity of the central banks' balance sheets (to which the democratic accountability consideration is obviously closely linked) and the ability to bring in foreign banks (despite their significance in the market place) is limited and diminishing. While this reduces the centrality of the role of the central bank in any LOLR process and thus reduces the significance of the transfer of supervisory powers, it does highlight the potential importance of crisis dialogue with the Treasury/Ministry of Finance, for which there has been no real precedent in the UK (nor possibly elsewhere).' 
structure in the eurozone, with a multiplicity of Finance Ministries, with a federal European System of Central Banks, and a variety of national supervisory bodies, becomes even more complex (see Goodhart (2000) and Louis (1995)). The administrative mechanisms for handling financial crises are becoming increasingly complex. Does that matter? Is it possible to handle financial crises by Committee? How much, if at all, have recent problems with resolving financial crises (e.g. in Japan) been due to such organisational problems?

Although there will be understandable reluctance to embark on contingency planning in this respect between the Bank of England, FSA and Treasury, the relative inexperience of the Treasury at such crisis decision-taking (meetings through weekends, market-critical announcements and deadlines that do not obligingly fit Parliamentary announcement timescales, etc.) does at least justify indicating this as a potentially major (both logistically and substantive) issue for the future.

Even if such organisational problems do exist, the main stumbling blocks to quick, correct and decisive action may arise primarily from other factors (e.g. the need of the politicians to generate public consensus for any action) than from the separation of banking supervision from the Central Bank. Is this latter a relatively minor, or a major issue? Since it may well depend on accidents of personality and the evolving culture of the supervisory body, how could anyone generalise, at least for many years to come?

${ }^{27}$ Following the Memorandum of Understanding in the UK between the Bank, FSA and Treasury such a tri-partite Standing Committee has regular monthly meetings, and would meet as frequently as required were a crisis to blow up. 


\section{(b) Information and the Conduct of Monetary Policy}

The transmission mechanism of monetary policy, whereby the effects of changes in the Central Bank's instruments, e.g. shortterm interest rates, eventually affect nominal incomes and inflation, largely flows through the intermediation of the banking system. An understanding of how the commercial banks may react to changes in interest rates, and in reserve availability, in their own decisions on lending and credit creation can be crucial in getting the macro-monetary policy decision right in the first place.

Under normal circumstances, when commercial banks are earning reasonably healthy profits and have adequately comfortable capital, worries about the effect of bank intermediation on the transmission mechanism will, as a rule, play second fiddle to other more direct concerns about inflationary pressures, e.g. wage/cost pressure, the output gap, demand pressures, etc. (though even then the growth rate of the monetary and credit aggregates will be valuable information variables). ${ }^{28}$

Nevertheless, and especially in countries where the banking system has proved fragile, there is some evidence that supervisory data can improve economic forecasting and analysis. ${ }^{29}$ The more troubled the banking system, the more essential such micro supervisory information may well be in order to reach correct macro decisions. ${ }^{30}$

\footnotetext{
28 In my own three years on the Monetary Policy Committee worries about the effects of structural developments in banking, as a potential factor to influence our own decisions, only surfaced briefly for a few months in the Autumn of 1998 when fears arose of a potential credit crunch in the USA, and (even less likely) in the UK; in the event this danger passed.

$\overline{{ }^{29}}$ See, for example, Peek, Rosengren and Tootell, (1998 and 1999).
} 
This point, that micro-level supervisory information may be a valuable input into macro-level monetary decisions, certainly during periods of financial instability, should not be novel, or contentious. But, the question then remains how much information, if any, would be lost, or corrupted, by the physical separation of banking supervision from the Central Bank to a separate unified institution? Is that question answerable? If so, how might one try to proceed to answer it?

It is, perhaps, not just, or not so much, the willingness of the separate supervisory body to supply information, relatively freely, to the Central Bank that is at question, ${ }^{31}$ but rather biasses to the kind of information that a supervisory body might seek on its own to obtain, dependent on whether it is inside, or separate from, a Central Bank. With the greater part of a unified supervisory authority working on customer protection issues, and with the professional skill base coming primarily from lawyers (in place of the Central Bank emphasis on systemic stability and a skill base of economics), will the banking supervisors in a unified supervisory agency lose sight of the wider macro issues? This is not to suggest that the supervisory authority would fail to be co-operative in providing such data as the Central Bank might

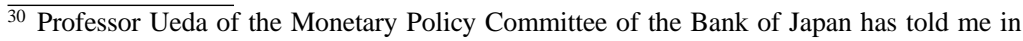
personal discussion of the considerable importance that he places on such information.

On the other hand, Alan Blinder (like me) is more sceptical. In his speech at the ECB Conference on December 3/4, 1999, reprinted in Monetary Policy-Making Under Uncertainty, (ECB, 2000), he stated:-

"My personal view is that the Fed has taken a grain of truth and greatly exaggerated its importance. Proprietary information that the central bank receives in bank examinations is of some, limited use in formulating monetary policy - and is on rare occasions very important. So, on balance, it is probably better to have it than not. On the other hand, a bank supervisor may sometimes have to be a protector of banks and sometimes a stern disciplinarian - and either stance may conflict with monetary policy."

$\overline{{ }^{31} \text { Certainly in cases }}$ when the macro-level monetary decisions might be significantly dependent on the state of the financial sector, then the FSA would contribute directly to the MPC's deliberations. 
request. Moreover the shock of separation may force the Central Bank to think more carefully and more rigorously exactly what micro-level data actually are needed. More care about detail and allocation of responsibility might emerge from separation. I have heard anecdotes to this effect in the Australian case.

Again, in the case of a large financial conglomerate, the Central Bank (and the Ministry of Finance) might have much better and more rapid access to information on the position of the group as a whole from a single integrated financial services regulator, than would be available in the world in which the conglomerate was overseen by multiple regulators (even if one of these regulators was located within the central bank). ${ }^{32}$

But what would be the priorities? And would the supervisor catch the early-warning signals of prospective systemic difficulties? If the Central Bank is bereft of its own micro-level information system, would it actually get to know what to ask for in the shape of data from the separate agency until any such problems had already appeared? And by then it might be too late. Or are such concerns purely fanciful?

Ferguson, op cit, puts these points vividly, p. 300:-

'A Central Bank that always must be ready to manage financial crises has to know - at a practical, institutional level - not only how financial markets and institutions operate but also how they are changing and how they are managed. I would even add that such a Central Bank needs to know which people make the management decisions and how their control and management information systems work. We do not need to supervise all institutions to accomplish this end. But we do need to be involved directly with a sufficient number to know how institutions in various size

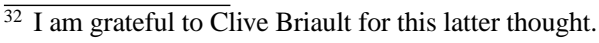


classes will respond to stress. I shudder to think about crisis management with staff without such knowledge and experience and without the international contacts with other Central Banks.'

There is also the question whether, having lost regular supervisory contact with the (main) banks, a Central Bank might become less capable of interpreting properly the information that it is given. The Federal Reserve has argued that they would need to remain familiar with such large systemic banks, e.g. by supervising them, in order to stay fully effective as a crisis manager. Be that as it may, I rather doubt whether those Central Banks without supervisory responsibility would take kindly to the suggestion that they could be losing their capacity to interpret supervisory information adequately. As so often in this field, the observer is struck by the ability of the participants to argue in favour of the current status quo, whatever that may be.

\section{c) The Payment System}

Alongside responsibility for macro-monetary price stability, and for maintaining systemic stability in the banking system (and to a lesser extent in the broader financial system), Central Banks have responsibility for ensuring the smooth working of the various payment systems in the economy, e.g. the ECB was charged, in the Maastricht Treaty, Article 105.2 with the task 'to promote the smooth operation of payment systems'. Sometimes they run these themselves, e.g. Fedwire, Target; sometimes they are just major participants. In all cases they have direct concern to see that they operate smoothly, without grid-lock, hitches or stoppages. The closure, or collapse, of such central infrastructure would be devastating.

How far can Central Banks accept responsibility for payment systems unless they have direct access to micro-level informa- 
tion on the viability of the other participants? Some structural changes, such as the adoption of RTGS (Real Time Gross Payments systems), of the Lamfalussy rules for net payments systems, of clearing houses interposing themselves between counterparties, e.g. the CLS bank in the foreign exchange market, and of PvP (Payment vs Payment) and PvD (Payment vs Delivery) can, and have, serve(d) to reduce risk in such systems.

Even so, there will remain, at least in some such systems, some residual risk. Information will be needed to assess that risk. Again the question remains whether the Central Bank needs direct access to its own sources of information on micro-level risk, or whether it can rely on a separate supervisory agency to supply it with appropriate data.

The same argument also runs in the opposite direction. If the Central Bank does manage the payment systems, then that could bring with it information of importance to the banking supervisors. If the supervisors are separated from the Central Bank, they in turn could find it more difficult to access relevant data. Pauli (2000) puts the point as follows, p. 19:-

'Typically problems first show up in a bank's payment traffic and its position vs the central bank. By managing banks' reserve and settlement accounts, the central bank automatically monitors continuously in real time the liquidity positions of individual banks. Furthermore, being active in the money market, the central bank receives first hand information on how each bank is perceived by the other market participant.'

\section{d) Information, Information, Information}

Prime Minister Blair is reported to have stated that the three main priorities for the UK were 'Education, Education, Education'. In the conduct of its various responsibilities for macro- 
monetary policy, systemic stability and the smooth working of the payments system, a Central Bank needs adequate microlevel information on the structural state of the major banks in its country in order to fulfil its duties adequately.

The question then arises whether the transfer of banking supervision to a separate (unified) authority outside of the banking system might potentially impair such information flows. But even if the answer is 'maybe', how does one balance such a consideration against the efficiency gain of having a unified supervisory authority within a unified financial system, and the various issues relating to bureaucratic power and 'turf' and possible conflicts of interest already identified in the previous Section?

The evidence appears to be that the weight of argument is moving towards the adoption of a separate unified supervisory body within more developed economies. But does that same balance hold for emerging and transitional countries? It is to this issue that we turn next. 


\section{Are the Issues the Same in Emerging Countries?}

The simple answer to the above question is 'no', though this needs to be qualified by the realisation that there is no clear dividing line between 'emerging' and developed countries, rather there is a continuum. Moreover, emerging countries are becoming increasingly developed. For example, the presence of financial conglomerates may differ markedly amongst them. Thus for countries such as Hungary or South Africa the arguments in the first three Sections may be more germane.

There are three main reasons for this generally negative answer. ${ }^{33}$ The first is that the financial structure in developing and transitional countries tends to be less complex, with more reliance on standard commercial banking (i.e. without the frills of

33 An additional reason why the separation model may not be such a good one for developing countries, as for developed, is that the quality of published information in developing countries is very poor. Thus, if we acknowledge that separation does lead to some deterioration in the flow of relevant information to the Central Bank, this leaves developing country Central Banks in a very difficult position. I am grateful to Patricia Jackson for this thought.

Yet another reason is that the legal system may also impact co-ordination between banking supervision and the central bank, and their ability to use MOUs as a means to institutionalise the flow of information and/or to co-ordinate decisions when there is an overlap in legal powers. Civil code systems tend to spell out in a very detailed way what each specific government agency may and may not do, while common law systems are more flexible in allowing institutions to adapt to changing economic and financial conditions. Most developing and transitional economies have civil code systems while developed countries, especially those that are at the forefront of modern prudential financial supervision, operate within common law legal systems. Legal systems also shape institutional culture, and civil code systems certainly tend to make inter-agency co-ordination more difficult. This is an argument in favour of having simpler, leaner institutional frameworks in developing and transitional countries. I am grateful to Ruth de Krivoy for making this point to me in private correspondence. 
other functions), than in developed economies. It is that complexity, and the blurring of boundaries, that forces either (i) Central Banking supervisors to extend far more widely beyond traditional limits, (ii) a multiplicity (two or more) of supervisors, or (iii) a unified supervisory body outside the Central Bank. This problem is not so stark in developing countries. In such countries separate supervisors for the banking system, insurance companies and, perhaps, the Stock Exchange can coexist without much friction or overlap. The arguments, in terms of efficiency, for a unified financial supervisory authority are not so strong at the earlier stages of development.

The second reason is that emerging countries have been more prone to systemic disturbances, especially in the aftermath of an initial liberalisation of the banking system. So the main focus of banking supervision in such countries has, perforce, been on systemic stability rather than on customer protection and conduct of business issues. So the connections between supervision and monetary policy, including LOLR operations, are more frequent and evident than in developed countries.

But the third and main difference in the case of emerging countries probably relates instead to the personnel and status of the supervisors themselves. In discussion of this issue amongst OECD countries, the main concern was whether separation of banking supervision from the Central Bank would adversely affect information flows to the latter. Even here, there was some attention paid to the question of whether the focus of a unified, separate financial authority would switch towards customer protection, rather than systemic stability, and whether its skill base would shift towards lawyers, as contrasted with economists.

Otherwise, however, it was (implicitly) assumed that within developed countries the organisational structure of (banking) 
supervision would not affect the overall financing, ability to hire the necessary skilled staff, or the independence from (political and commercial) pressures (i.e. the ability to resist corruption) of the supervisors themselves. This assumption, that organisational structure will not affect staffing, cannot be made in many developing countries.

Central Banks in developing countries tend to have more independence from political and commercial pressures than most other organisations, and also tend to be better financed. This is in some large part because governments need Central Banks to act on their behalf as specialist experts in international financial dealings. If such Central Bankers are not both expert and able to provide a source of independent advice, they would not be credible and effective in such a context, especially in the collegial, and quite frequent, gatherings of international Central Bankers. The informal club of Central Banks has influence. Again, the ability of the domestic government to prevent financial instability, and a flight from its currency both internally and externally, will depend in part on the perceived expertise, independence and credibility of the Central Bank and its Governor. Moreover, as the initial recipient of seigniorage, sometimes the most reliable source of government funding during troubled times, the Central Bank is comparatively well placed in developing countries to achieve and to maintain adequate funding.

The Central Bank is, therefore, an institution which can often provide satisfactory levels of expertise, independence and funding in a country where these may be in short supply. ${ }^{34}$ If banking

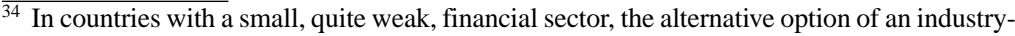
funded supervisory body is hardly available, and would anyhow be more subject to 'capture'. So, the main alternative to a Central Bank supervisory body is one run by government. A major concern with government funding of regulation is that budgetary pressures can lead to arbitrary cuts in the regulation budget; examples from developed, as well as developing, countries are, alas, only too common.
} 
supervisors come under the umbrella of the Central Bank they are more likely to share in the good fortune of better, and more independent, staff and stronger funding.

A dramatic case of such matters is provided by Ruth de Krivoy in her recent book, Collapse: The Venezuelan Banking Crisis of 1994. Let me first provide three examples, relating to Venezuela, from Chapter 1.

First, outside the Central Bank, there will be political interference with supervisors:-

'All financial sector regulatory authorities reported to the minister of finance. The minister, appointed by the President, had tremendous personal power in deciding how banks would be treated. The superintendent of banks, who reported to him, was in charge of regulating, supervising and sanctioning banks. Yet he lacked the power to take key actions, such as intervening in ailing financial institutions, authorizing the establishment of new ones and approving changes in a bank's capital base. The superintendent could not authorize the sale, merger or dissolution of a financial institution, or suspend or revoke its operating license. The minister of finance had control over these areas, and highly discretionary powers. That meant a bank depended directly on the will of a minister for its survival. Thus, the most important rules could be, and often were, managed on a political basis.' p. 24.

Second, outside the Central Bank, there is a greater likelihood of corruption, and inefficiency:-

'Accounting rules and prudential norms, covering areas such as loan classification, asset valuation, provisioning, income accounting and lending to affiliated parties, were also inadequate. The Office of the Superintendent of Banks received mountains of data, undertook ritualistic scrutiny of financial statements and remained largely in the dark. The longstanding requirement that 
banks publish their monthly balance sheets and half-yearly income statements in newspapers was also inconsequential. Instead of providing real information, these statements were often riddled with window dressing and misleading creative accounting. Because the regulations themselves were meaningless, banking supervision became generally lax and ineffective in practice. Additionally, the Office of the Superintendent of Banks carried the stigma of corruption (Oscar Garcia Mendoza, Crónica involuntaria de una crisis inconclusa. (Caracas: Editorial Planeta de Venezuela, 1995), p. 194). Bluntly put, supervision had become a meaningless ritual, no matter who held the job. There may have been formal monitoring of compliance, but there was no ongoing analysis of the solvency of Venezuela's financial institutions. As a result, bank assets were simply not what they appeared to be.'

Third, outside a Central Bank, funding for banking supervision is less likely to be adequate:-

'Technological, financial and personnel resources with which the government could have implemented supervision dwindled with the deterioration of public finances, reaching record lows after 1989. Neither the government nor most legislators cared. Banking supervision was simply not a political priority. On the eve of the 1994 banking crisis, the Office of the Superintendent of Banks had a staff of 60 to supervise more than 150 financial institutions. While the banking system's technological capabilities were state-of-the-art, the Office of the Superintendent of Banks had virtually no data processing capability. Banking law required supervisors to conduct an on-site inspection of each bank at least once a year. Yet the superintendent's annual budget had dwindled to about $\$ 8,000$ per financial institution - less than the annual salary of a mid-level clerk. On-site inspections when conducted - were largely ceremonial, hand-shaking affairs. Many banks were not inspected for years.' p. 26. 
Not surprisingly, therefore, one of her main conclusions is that the Central Bank should 'Play a role in banking supervision, since the central bank is the lender of last resort', p. 203. She emphasises three requirements, as follows:-

'The institutional framework will best serve to promote stable money and sound and safe banking if it:-

* rests upon politically independent institutions, * allows proper coordination between monetary policy and banking regulation and supervision, and

* enables officials to anticipate systemic risk and to react to it in a timely and efficient manner.

Giving supervisory powers to an independent central bank is especially advantageous if public institutions are weak, coordination between different public sector agencies is troublesome, or skilled human resources are scarce. Central banks are usually a country's most prestigious and well-equipped institutions, and are in a good position to hire, motivate and keep skilled staff.' pp. 203/4.

However pointed, this is but one single example. Yet at a session of the Central Bank Governors' Symposium on Financial Regulation and Supervision at the Bank of England, Friday, June 2nd, 2000, many of the same points were made by the participating Governors. Thus Mr. Venner of the Eastern Caribbean Central Bank noted that "no one else [except the Central Bank] was there in a disinterested way', e.g. to mediate between foreign and domestic banks, and that the Central Bank was best placed to maintain auditing standards. Dr. Marion Williams of the Central Bank of Barbados stated that, 'If the Central Bank has to pick up the pieces, it should have charge of preventative measures', a point echoed by Mr. Alweenoo of the Bank of Namibia. Mr. Joseph Yam of Hong Kong emphasised 'The crucial importance of a high degree of cooperation and information 
sharing'. Mr. Hamad Al Sayri argued that it was important not 'to spread the know-how too thin'. Many similar points were made. ${ }^{35}$

One of the purposes of the survey being undertaken by Schoenmaker and myself is to try to throw some light on the relative skill base of supervisors, both by organisational structural form (e.g. within or outside Central Banks) and by stage of development. It is uncertain whether any such qualitative exercise can provide any clear, quantitative results. Nevertheless a combination of anecdote and experience (admittedly mostly observed through a Central Banking prism) does suggest that banking supervision in developing countries has been rather better done if taken under the wing of a Central Bank.

Even if that were so in the past, i.e. that banking supervision in developing countries is done generally better under the aegis of a Central Bank, this will not necessarily hold in the future. The weaknesses of national supervisory bodies have come under the international spotlight as a consequence of recent financial crises, e.g. in Asia. It is possible that international pressures, e.g. through the IMF, will interact with domestic forces to lead towards better funded, more skilled and more independent supervisory bodies irrespective of how these are structurally organised.

$\overline{35}$ Cynics will say that Central Banks were just seeking to protect their own turf. But many of the arguments set out in Section (II) here for separating supervision from Central Banking were also raised, e.g. the diversion of executive time (Dr. Fraga of Brazil and Mr. Gunnarson of Iceland), and the legal problems of being a supervisor and having to intervene in the governance of commercial banks (Mr. Massad of Banco Central de Chile). When Mr. Yong Guan Koh of the Monetary Authority of Singapore argued that the integration of supervision with a broader Monetary Authority facilitated career planning (as well as promoting a quicker response to arising problems), Mr. George of the Bank of England replied that this was dubious since many of the analytical skills required in supervision, (e.g. accountancy, customer relations) were less in need in other areas of a Central Bank. 
If so, then structure may come not to be an important issue for the conduct of banking supervision. Perhaps, but for the time being the balance of argument would suggest that in less developed and transitional economies it would be safer and better to integrate banking supervision into the ambit of the Central Bank. 



\section{Conclusions}

The arguments for separating banking supervision from Central Banks, and placing this within a unified financial supervisory agency, have become increasingly powerful in recent years, more particularly in developed countries with complex financial systems. The blurring of functional boundaries has led to a seamless financial system; so efficiency suggests that a unified financial supervisor should mark that system. Add in perennial concerns about putative conflicts of interest, and a worry whether an (operationally) independent Central Bank with added supervisory functions might become too powerful within a democratic context, and the result is a potent cocktail of reasons for such a change.

The counter-argument rests on fears whether the information base needed by a Central Bank to carry out its various essential functions might be less good if it did not have direct control of banking supervision in-house. While there are some reasons adduced for such concerns within developed countries, they are, as yet, somewhat speculative. Why cannot information flows be almost as good between agencies, as when they are internalised within the same institution? If so, the above arguments for a unified financial supervisory authority tend to become dominant. It is, however, the thesis of Section (IV) above that there are much stronger reasons to believe that the conduct of banking supervision will be better done under the wing of the Central Bank in less developed countries. Within a Central Bank, supervisors in such countries are, I claim, likely to be better funded, more independent and hence more expert and reliable.

Apart from case studies, experience and anecdote there is not much hard evidence to go on, especially on this latter subject. 



\section{Bibliography}

Abrams, R. and M. Taylor, (forthcoming), 'Issues in the Unification of Financial Sector Supervision', IMF Working Paper.

Bank for International Settlements (BIS), (2000), Annual Report, (June), (BIS: Basel).

Benston, G. and G. Kaufman, (1995), 'Is the Banking and Payment System Fragile?', Journal of Financial Services Research, 9, 209-40.

Blinder, A., (2000), Conference presentation in Monetary Policy-Making under Uncertainty, (European Central Bank: Frankfurt).

Board of Governors of the Federal Reserve System, (1994), 'Views on the Consolidation of Bank Supervision and Regulation', Memorandum presented to the United States Committee on Banking, Housing and Urban Affairs, (March).

Borio, C. and R. Filosa, (1994), 'The Changing Borders of Banking: Trends and Implications', BIS Economic Paper, No. 43, (December).

Briault, C., (1997), Discussant to F. Bruni, Chapter 11 in Towards More Effective Monetary Policy, ed. I. Kuroda, (Macmillan: London), pp. 379-86.

Briault, C., (1999), 'The Rationale for a Single National Financial Services Regulator', FSA Occasional Paper Series, No. 2/1999, (May).

Bruni, F., (1997), 'Central Bank Independence in the European Union', Chapter 11 in Towards More Effective Monetary Policy, ed. I. Kuroda, (Macmillan: London), pp. 341-69.

Courtis, N. (ed.), (1999), How Countries Supervise their Banks, Insurers and Securities Markets, (Central Banking Publications: London). de Krivoy, R., (2000), Collapse: The Venezuelan Banking Crisis of 1994, (Group of Thirty: Washington, D.C.).

Di Noia, C. and G. Di Giorgio, (1999), 'Should Banking Supervision and Monetary Policy Tasks be Given to Different Agencies?', International Finance, 2(3), (November), 361-78.

Dubouchet, T., (2000), 'Les organes de supervision bancaire au sein de l'UEM', (publication forthcoming), extract, pp. 346-97, from Doctoral Thesis, Economics Department, Université Lumière Lyon 2, on 'La Politique Micromonétaire'.

Ferguson, R., (2000), 'Alternative Approaches to Financial Supervision and Regulation', Journal of Financial Services Research, 17(1), 297-303.

Financial Services Authority (FSA), (2000), 'A New Regulator for the New Millennium', pamphlet.

Goodhart, C., (ed.), (2000), Which Lender of Last Resort for Europe?, (Central Banking Publications: London).

Goodhart, C., Hartmann, P., Llewellyn, D., Rojas-Suárez, L. and S. Weisbrod, (1998), Financial Regulation: Why, How and Where Now?, (Routledge: London).

Goodhart, C. and D. Schoenmaker, (1995a), 'Institutional Separation between Supervisory and Monetary Agencies', in The Central Bank and the Financial System, ed. C.A.E. Goodhart (Macmillan: London), Chapter 16.

Goodhart, C. and D. Schoenmaker, (1995b), 'Should the Functions of Monetary Policy and Banking Supervision be Separated?', Oxford Economic Papers, 40, 539-60.

Greenspan, A., (1994), Testimony on banking regulation, before the United States Senate Committee on Banking, Housing and Urban Affairs, (March 2). 
Group of Thirty (G30), (1997), Global Institutions, National Supervision and Systemic Risk, (pamphlet), (G30: Washington, D.C.).

Haubrich, J., (1996), 'Combining Bank Supervision and Monetary Policy', Economic Commentary, 11, 1-9.

Heller, H.R., (1991), 'Prudential Supervision and Monetary Policy' in International Financial Policy: Essays in Honour of Jacques J. Polak, eds., J.A. Frenkel and M. Goldstein, (International Monetary Fund: Washington, D.C.), 269-81.

Kaufman, G., (1996), 'Bank Failures, Systemic Risk, and Bank Regulation', Cato Journal, 16(1), (Spring/Summer), 17-45.

Kaufman, H., (2000), 'On Money and Markets', (McGraw-Hill: New York).

Krivoy, R.d., (2000), Collapse: The Venezuelan Banking Crisis of 1994, (Group of Thirty: Washington, D.C.).

Laidler, D., (1998), 'Monetarism, Microfoundations and the Theory of Monetary Policy', The Centre for the Study of International Economic Relations, University of Western Ontario, Working Paper No. 88076.

Lannoo, K., (1999), 'Challenges to the Structure of Financial Supervision in the EU', Centre for European Policy Studies (CEPS), (Brussels).

Louis, J.-V. et al., (1995), Banking Supervision in the European Community Institutional Aspects, (Editions de l'Université de Bruxelles: Brussels), Report of a Working Group of the ECU Institute Composed of J.V. Louis, Chairman, I. Begg, E. Garcia de Enterria, N. Horn, E. de Lhoneux, L. G. Radicati di Brozolo, R. Smits and J. Stoufflet.

Mendoza, O.G., (1995), Crónica involuntaria de una crisis inconclusa, (Editorial Planeta de Venezuela: Caracas).

Pauli, R., (2000), 'Payments Remain Fundamental for Banks and Central Banks', Bank of Finland Discussion Papers, (6/2000).
Peek, J., Rosengren, E. and G. Tootell, (1999), 'Is Bank Supervision Central to Central Banking', Quarterly Journal of Economics, 114, 629-53.

Peek, J., Rosengren, E. and G. Tootell, (1998), 'Does the Federal Reserve have an Informational Advantage? You can Bank on it', Federal Reserve Bank of Boston, Working Paper No. 98-2, (April).

Schwartz, A., (1995), 'Systemic Risk and the Macroeconomy' in G. Kaufman, ed., Research in Financial Services, 7:19-30, (JAI Press: Greenwich).

Shadow Financial Regulatory Committee (USA), (1993), Statement on 'The Proposed Federal Banking Commission', No. 100, (December).

Shadow Financial Regulatory Committee (USA), (1998), Statement on 'The Federal Reserve Board and Prudential Supervision', No. 153, (December).

Taylor, M., (1995), Twin Peaks: A Regulatory Structure for the New Century, (pamphlet), (Centre for the Study of Financial Innovation, CSFI: London), (December).

Taylor, M., (1996), Twin Peaks: How to Reform the UK's Regulatory System, (pamphlet), (CSFI: London), (October).

Taylor, M. and A. Fleming, (1999), 'Integrated Financial Supervision: Lessons from Northern European Experience', World Bank, Policy Research Working Paper, No. 2223, (November).

Tuya, J. and L. Zamalloa, (1994), 'Issues on Placing Banking Supervision in the Central Bank', in T. Balino and C. Cottarelli, eds., Framework for Monetary Stability, (IMF: Washington, D.C.).

Volcker, P., (1984), 'The Federal Reserve Position on Restructuring of Financial Regulation Responsibilities', Federal Reserve Bulletin, 70, (July), 547-57.

Wallis Committee Report, (1997), Financial System Ingiving: Final Report, (Australian Government Publishing Company: Canberra). 